\title{
Oxidation of essential amino acids by the ovine gastrointestinal tract
}

\author{
Gerald E. Lobley*, Xiangzhen Shen†, Guowei Leł, David M. Bremner, \\ Eric Milne, A. Graham Calder, Susan E. Anderson and Ngaire Dennison \\ Rowett Research Institute, Greenburn Road, Bucksburn, Aberdeen AB21 9SB, UK
}

(Received 5 September 2002 - Revised 9 December 2002 - Accepted 28 December 2002)

\begin{abstract}
It is not known if the ruminant animal gastrointestinal tract (GIT) can oxidise essential amino acids (AA) other than leucine. Therefore, the oxidation of four essential AA (leucine, lysine, methionine and phenylalanine), supplied systemically as labelled $1-{ }^{13} \mathrm{C}$ forms, was monitored across the mesenteric-drained viscera (MDV; small intestine) and portal-drained viscera (PDV; total GIT), as part of a $4 \times 4$ Latin square design, in four wether sheep $(35-45 \mathrm{~kg}$ ) fed at $1.4 \times$ maintenance. Oxidation was assessed primarily by appearance of ${ }^{13} \mathrm{CO}_{2}$, corrected for sequestration of $\left[{ }^{13} \mathrm{C}\right]$ bicarbonate. The GIT contributed $25 \%(P<0.001)$ and $10 \%$ $(P<0.05)$ towards whole-body AA oxidation for leucine and methionine respectively. This reduced net appearance across the PDV by 23 and $11 \%$ respectively. The contribution of MDV metabolism to total PDV oxidation was $40 \%$ for leucine and $60 \%$ for methionine. There was no catabolism of systemic lysine or phenylalanine across the GIT. Production and exchange of secondary metabolites (e.g. 4-methyl-2-oxo-pentanoate, homocysteine, 2-aminoadipate) across the GIT was also limited. Less AA appeared across the PDV than MDV $(P<0.001)$, indicative of use by tissues such as the forestomach, large intestine, spleen and pancreas. The PDV: MDV net appearance ratios varied $(P<0.001)$ between AA, e.g. phenylalanine $(0.81)$, lysine $(0.71)$, methionine $(0.67)$, leucine $(0.56)$, histidine $(0.71)$, threonine $(0.63)$ and tryptophan (0.48). These differences probably reflect incomplete re-absorption of endogenous secretions and, together with the varied oxidative losses measured, will alter the pattern of AA net supply to the rest of the animal.
\end{abstract}

Gastrointestinal tract: Oxidation: Leucine: Methionine: Lysine: Phenylalanine: Sheep

It is well recognised that the gastrointestinal tract (GIT) makes a major contribution to whole-body energy and protein metabolism. For example, in sheep the GIT contributes approximately $25 \%$ total $\mathrm{O}_{2}$ consumption (Burrin et al. 1989) and as much as $65 \%$ to whole-body protein synthesis (WBPS; MacRae et al. 1997a). While this high metabolic activity is undoubtedly necessary to ensure effective organ function to meet the demands of digestion, absorption and provision of an innate immune defence, this may incur a cost. Incomplete resorption from the lumen of endogenous secretions and desquamed cells can result in reduced amino acid (AA) availability to other tissues, both in total amount and the relative composition (van Goudoever et al. 2000; Lapierre \& Lobley, 2001). The GIT also can catabolise (oxidise) $\mathrm{AA}$, as has been clearly demonstrated, in both ruminant and non-ruminant animals, for glutamate and glutamine (Wolff \& Bergman, 1972; Reeds et al. 2000; Reeds \& Burrin, 2001). Such catabolism is probably linked to the energy needs of the GIT (Reeds et al. 2000).

The extent to which essential AA may be catabolised by the GIT is less clear, with results available for only a few AA. In ruminant animals, for example, reported studies have only used leucine, which is catabolised by the GIT with the extent determined by a range of factors that include diet quantity (Pell et al. 1986; Yu et al. 2000), diet quality (Lobley et al. 1996b; Lapierre et al. 2002), the presence of intestinal tract parasites ( $\mathrm{Yu}$ et al. 2000) and use of antibiotics directed against the GIT microflora (MacRae et al. 1999). In consequence, 25-50\% of leucine absorption may be oxidised across the GIT. The question, then, is do the other essential AA behave similarly to

\footnotetext{
Abbreviations: AA, amino acid; GIT, gastrointestinal tract; MDV, mesenteric-drained viscera; MOP, 2-oxo-4-methylpentanoate; PDV, portal-drained viscera; WBO, whole-body oxidation; WBPS, whole-body protein synthesis.

* Corresponding author: Dr G. E. Lobley, fax +44 1224 716629, email g.lobley@rowett.ac.uk

$\dagger$ Present address: College of Veterinary Medicine, Nanjing Agricultural University, Nanjing, P. R. China.

$\ddagger$ Present address: School of Food Science and Technology, Southern Yangtze University, Wuxi City, Jiangsu 204136, P. R. China.
} 
leucine? There is evidence that lysine is also oxidised by the pig GIT, provided that dietary protein supply is high (van Goudoever et al. 2000). In contrast, threonine is not catabolised in young pigs (Burrin et al. 2001), indicative of preferential rather than global responses.

A further issue relates to the site of any GIT oxidation. Does this occur predominantly in the tissues of the small intestine? If so, then the absolute amount of essential AA appearance in the mesenteric vein should be less than absorption of diet-derived AA (i.e. disappearance from the lumen of the small intestine). This is apparently not the case with sheep and cattle (MacRae et al. 1997b; Berthiaume et al. 2001), but reduced amounts do appear in the portal vein. While one explanation might involve metabolism of AA by the rumen tissues, there are similar quantitative and relative losses across the pig GIT (van Goudoever et al. 2000). Such results would imply that the GIT has a major impact on the amount of AA available to peripheral tissues and treatments that reduce the metabolic activity of the digestive tract would enhance growth or lower protein requirements for maintenance of lean mass. It is necessary, therefore, to determine if AA are oxidised by the GIT or may be lost by other routes, e.g. non-reabsorption of endogenous secretions.

The current study addresses this issue in sheep and investigates the capability of both the small intestine and total GIT to oxidise four essential AA extracted from the systemic circulation. Leucine was selected as representative of the branched-chain AA and because of known catabolism by the GIT. Methionine and lysine were also examined as either are often considered first limiting in typical ruminant animal diets (National Research Council, 2001) and any losses during absorption will restrict further any potential anabolism. In addition, conversion of methionine to homocysteine, and then probably to cysteine, occurs in both the ovine (Lobley et al. 1996a) and digestive tract of human subjects (Stegink \& den Besten, 1972). Phenylalanine was chosen to represent the aromatic AA and, for which catabolism in non-hepatic tissues is know to occur in other species (Bush et al. 2003). In addition to these direct measurements of oxidation, from differences in net appearances in the mesenteric and portal veins of other individual AA, the impact of oxidative or secretory losses could be assessed.

\section{Materials and methods}

\section{Animals and diet}

Four Suffolk cross wether lambs $(35-45 \mathrm{~kg}, 8-10$ months old) were prepared with indwelling silicone rubber catheters in the aorta, portal vein, hepatic vein and two in the mesenteric vein as described previously (Lobley et al. 1995). For the two mesenteric vein catheters, the more cranial was inserted via a side-branch approximately $0.20 \mathrm{~m}$ from the gastro-splenic junction and the tip advanced to be $0.05 \mathrm{~m}$ distal to that junction. The more distal catheter was inserted via a side-branch at least $0.25 \mathrm{~m}$ from the insertion of the other catheter and the tip advanced $0.10 \mathrm{~m}$ into the mesenteric vein in the direction of blood flow. This preparation allowed blood to be collected across the mesenteric-drained viscera (MDV) and the portal-drained viscera (PDV; Fig. 1). The MDV drained blood from the small intestine between a point approximately $0.50 \mathrm{~m}$ caudal to the pylorus through to the ileum. The PDV also drained those tissues plus the forestomachs, the first $0.50 \mathrm{~m}$ of the duodenum, the hindgut, spleen and pancreas. Animals were allowed 2 weeks to recover from surgery and then were adjusted to metabolism cages and offered $1.2 \mathrm{~kg}$ grass pellets (as fed)/d (964 g DM $/ \mathrm{kg} ; 23 \mathrm{~g} \mathrm{~N}$ and 10.5 MJ estimated metabolisable energy $/ \mathrm{kg} \mathrm{DM}$ ), supplied as twenty-four equal portions at hourly intervals by means of automated feeders. In addition, $50 \mathrm{~g}$ mixed concentrate-forage diet $(\mathrm{g} / \mathrm{kg}$ : hay 500, barley 300, molasses 100 , fishmeal 90 , vitamins and minerals $10 ; 11.7 \mathrm{~g} \mathrm{~N} / \mathrm{kg}$ as fed) were given each morning. Therefore, total $\mathrm{N}$ intake was $798 \mathrm{mmol} / \mathrm{h}$.

Each sheep was studied on five separate occasions. The first four periods comprised part of a $4 \times 4$ Latin square design that involved quantification of the metabolism of the four AA. Each measurement period involved a $10 \mathrm{~h}$ intra-hepatic vein infusion of a $1-{ }^{13} \mathrm{C}$-labelled form of one of the AA. Rates of infusion were: L- $\left[1-{ }^{13} \mathrm{C}\right]$ leucine (99.1 atom \%; Mass Trace Inc., Woburn, MA, USA) $0.70 \mathrm{mmol} / \mathrm{h}$; L- $\left[1-{ }^{13} \mathrm{C}\right]$ methionine $(98.7$ atom $\%$; Isotec Inc., Miamisburg, OH, USA) $0.23 \mathrm{mmol} / \mathrm{h}$; L-[1- $\left.{ }^{13} \mathrm{C}\right]$ phenylalanine (99 atom \%; Mass Trace Inc.) $0.33 \mathrm{mmol} / \mathrm{h}+\mathrm{L}-\left[{ }^{2} \mathrm{H}_{4}\right.$ ]tyrosine (99 atom \%; Isotec Inc.) $0.07 \mathrm{mmol} / \mathrm{h}$. For lysine, limited availability meant that different forms were infused $(0.23 \mathrm{mmol} / \mathrm{h})$ in separate sheep; either $\mathrm{L}-\left[1-{ }^{13} \mathrm{C}\right]$ lysine (99 atom \%; Isotec Inc.) or $\mathrm{L}-\left[1-{ }^{13} \mathrm{C},{ }^{2} \mathrm{H}_{2}\right]$ lysine (98 atom \%; Cambridge Isotope Laboratories, Andover, MA, USA). Following the last infusion of the $4 \times 4$ Latin square design, all animals received a fifth $10 \mathrm{~h}$ infusion of sodium $\left[1-{ }^{13} \mathrm{C}\right]$ bicarbonate $(0.30 \mathrm{mmol} / \mathrm{h} ; 98$ atom \%; Isotec Inc.).

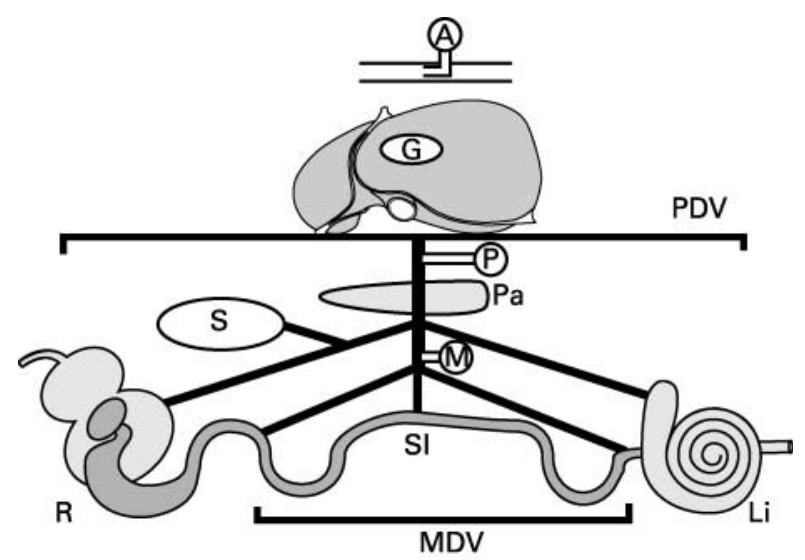

Fig. 1. Vascular drainage of the gastrointestinal tract and positions of catheters for blood sampling. All blood to the gastrointestinal tract is derived from arterial sources, represented by aortal blood (catheter A). The mesenteric-drained viscera (MDV) supplies blood to the mesenteric vein (catheter M) from the small intestine (SI) between approximately $0.50 \mathrm{~m}$ caudal to the pylorus and the ileum. The portal-drained viscera (PDV) includes blood in the portal vein (catheter $\mathrm{P}$ ) derived from the MDV plus forestomachs (from rumen (R) to first $0.50 \mathrm{~m}$ of duodenum), large intestine (LI), spleen (S) and pancreas $(\mathrm{Pa})$. Secretions derived from saliva and the gall bladder ( $G$, as bile inflows) enter the rumen and small intestine respectively, but are derived from vascular sources beyond the PDV. 
All infusates were prepared in $200 \mathrm{~g}$ sterile $0.15 \mathrm{M}-\mathrm{NaCl}$ and infused at $20 \mathrm{~g} / \mathrm{h}$ into the hepatic vein, except for the phenylalanine-tyrosine mixture which was dissolved in $400 \mathrm{~g}$ sterile $0 \cdot 15 \mathrm{M}-\mathrm{NaCl}$ and infused at $40 \mathrm{~g} / \mathrm{h}$. A minimum of $4 \mathrm{~d}$ was left between each infusion. A solution of sterile $0 \cdot 1 \mathrm{M}$-sodium $p$-aminohippurate in $0.05 \mathrm{M}$-sodium phosphate $\mathrm{pH} 7.4$ containing $250 \mathrm{IU}$ heparin/g (Leo Laboratories Ltd, Princes Risborough, Bucks., UK) was infused $(40 \mathrm{~g} / \mathrm{h})$ into the distal mesenteric vein catheter between $3 \cdot 5-10 \cdot 0 \mathrm{~h}$ of labelled AA or bicarbonate infusion. During all infusions the animals continued to be fed on an hourly basis, i.e. all measurements involve absorptive periods.

Continuous integrated blood samples $(11 \mathrm{ml})$ were withdrawn hourly from each of the cranial mesenteric vein, portal vein and aortal catheters between $6-9 \mathrm{~h}$ of AA infusion and collected into syringes over ice (Lobley et al. 1995). On the day preceding each infusion of labelled material, a solution of sterile $0.15 \mathrm{M}-\mathrm{NaCl}$ containing $250 \mathrm{IU}$ heparin/g was infused into the mesenteric vein for $2 \mathrm{~h}$, with $3 \times 40$ min integrated samples withdrawn $(7 \mathrm{ml})$ from the other three catheters to provide natural abundance ('background') samples for bicarbonate and AA enrichments. All samples from natural abundance and labelled AA infusions were mixed in the syringes and triplicate samples $(1 \mathrm{ml})$ injected into evacuated red-topped Vacutainers (Beckton Dickinson, Plymouth, Devon, UK) containing $0.9 \mathrm{ml}$ lactic acid. These were immediately mixed to liberate $\mathrm{CO}_{2}$ and, on the same day, enrichments measured, based on ion intensities at masses 44, 45 and 46 by dual-inlet gas isotope MS (SIRA 12; VG Isogas, Middlewich, Ches., UK). Calculated atom \% values included the Craig correction to allow for the presence of atmospheric ${ }^{17} \mathrm{O}_{2}$ that would yield ${ }^{12} \mathrm{C}^{17} \mathrm{O}^{18} \mathrm{O}$ with a mass of 45; this would interfere with the quantification of ${ }^{13} \mathrm{CO}_{2}$. Atom $\%$ excess values were calculated by difference from the natural abundance samples.

Blood haemoglobin, $P_{\mathrm{O}_{2}}, P_{\mathrm{CO}_{2}}, \mathrm{pH}$ and packed cell volume were determined in duplicate using an ABL625 Blood Gas Analyser (Radiometer, Copenhagen, Denmark). The remaining blood was then centrifuged at $1000 \mathrm{~g}$ for $15 \mathrm{~min}$ at $4^{\circ} \mathrm{C}$ to obtain plasma. $\mathrm{NH}_{3}$ concentrations were determined, in duplicate, in $0.4 \mathrm{ml}$ fresh plasma by the glutamate dehydrogenase reaction using a Kone Dynamic Selective Analyser (Kone, Espoo, Finland). The $p$-aminohippurate concentrations in $0.7 \mathrm{~g}$ fresh plasma were determined gravimetrically as described previously (Lobley et al. 1995). To a further $0.7 \mathrm{~g}$ plasma was added a known weight $(0.3 \mathrm{~g})$ of a solution containing $0.6 \mathrm{mg}$ hydrolysed $\left[\mathrm{U}_{-}{ }^{13} \mathrm{C}\right]$ algae powder (99 atom \%; Martek Biosciences Corp., Colombia, MD, USA), $200 \mathrm{nmol}\left[5{ }^{15} \mathrm{~N}\right]$ glutamine (99 atom \%, Mass Trace Inc.), $100 \mathrm{nmol}$ [indole- ${ }^{15} \mathrm{~N}$ ]tryptophan (99 atom \%, Cambridge Isotope Laboratories) and $3.48 \mu \mathrm{mol}$ $\left[{ }^{15} \mathrm{~N}^{15} \mathrm{~N}\right]$ urea (99 atom \%; Mass Trace Inc.). These samples were mixed and then frozen $\left(-80^{\circ} \mathrm{C}\right)$ until analysis as the $t$-butyldimethylsilyl derivatives to determine AA and urea concentrations as molal concentrations by isotope dilution with GC-MS, as described previously (Calder et al. 1999).

Another portion of plasma $(1 \mathrm{~g})$ was frozen $\left(-80^{\circ} \mathrm{C}\right)$ for later analysis of the enrichments of the AA and appropriate metabolites. The plasma samples for subsequent analysis of methionine had $0.1 \mathrm{ml} 100 \mathrm{~mm}$-dithiothreitol added before freezing to allow subsequent release and analysis of homocysteine bound to plasma protein and, on thawing, this plasma was left at room temperature for $30 \mathrm{~min}$ before deproteinisation. All thawed plasma was deproteinised with $0.15 \mathrm{ml}$ sulfosalicylic acid $(480 \mathrm{~g} / \mathrm{l})$ and, after centrifugation, the supernatant fraction was applied to $0.7 \mathrm{ml}$ AG-50 resin (100-200 mesh $\times$ 8) in the $\mathrm{H}^{+}$form followed by $1 \mathrm{ml}$ deionised water wash. The eluate plus washings were collected and the oxo-acids of leucine (2-oxo-4-methylpentanoate, MOP) and 2-aminobutyrate (2-oxobutyrate) extracted and converted to the quinoxanol $t$-butylmethylsilyl derivative prior to $\mathrm{GC}-\mathrm{MS}$ (Calder \& Smith, 1988). The AA and other metabolites were then eluted with $2 \mathrm{ml} 2 \mathrm{M}-\mathrm{NH}_{4} \mathrm{OH}$ followed by $1 \mathrm{ml}$ deionised water. From the combined eluate, $80 \mu \mathrm{l}$ was removed for urea analysis after drying under $\mathrm{N}_{2}$ gas, while the remainder was freeze-dried. The urea, AA and amino-derivatives were converted to the $t$-butylmethylsilyl derivatives and analysed by GC-MS using a Hewlett Packard HP5989A Engine (Hewlett Packard, Avondale, PA, USA) as described previously (Calder \& Smith, 1988). The respective $\mathrm{m} / \mathrm{z}$ monitored were: leucine 302 , 303 ; methionine 321, 322; lysine 300, 301 for $\left[1-{ }^{13} \mathrm{C}\right]$ lysine and 300,303 for $\left[1-{ }^{13} \mathrm{C},{ }^{2} \mathrm{H}_{2}\right]$ lysine; phenylalanine 336,337 ; tyrosine 466,467 (for $\left[1{ }^{2}{ }^{13} \mathrm{C}\right]$ tyrosine synthesised from $\left[1-{ }^{13} \mathrm{C}\right]$ phenylalanine), 470 (for $\mathrm{m}+4$ ions from $\left[{ }^{2} \mathrm{H}_{4}\right]$ tyrosine); homocysteine 420,421 ; 2-aminobutyrate 274, 275; homoserine 404, 405; 2-aminoadipate 446,447 or 449 depending on the labelled lysine infused. For the oxo-acids, the $\mathrm{m} / \mathrm{z}$ ions monitored were: MOP 259,$260 ; 2$-oxobutyrate 231, 232. All calculations of molar \% excess were as described by Campbell (1974), based on the ratio differences against the natural abundance values.

\section{Calculations}

Net transfers $(\mu \mathrm{mol} / \mathrm{h})$ across the MDV or PDV were calculated as:

$$
\left(\mathrm{M}_{\mathrm{m}} \text { or } \mathrm{p}-\mathrm{M}_{\mathrm{a}}\right) \times \mathrm{PF}_{\mathrm{m}} \text { or } \mathrm{p}
$$

where $\mathrm{M}$ is metabolite (AA, urea, $\mathrm{NH}_{3}$ or bicarbonate) concentration $(\mu \mathrm{M}), \quad \mathrm{PF}$ is plasma flow $(\mathrm{kg} / \mathrm{h}$ from gravimetric $p$-aminohippuric acid measurements) and $\mathrm{m}$ is mesenteric, $\mathrm{p}$ is portal and $\mathrm{a}$ is arterial sample respectively. For these, and subsequent trans-organ calculations, values were calculated for individual plasma flows and concentration differences for each of the three hourly periods on each measurement day and then the mean value used for subsequent statistical analyses.

Whole-body tracee AA irreversible loss rate $(\mathrm{mmol} / \mathrm{h})$ was calculated from:

$$
\left(I_{e} / E_{a}-1\right) \times I,
$$

where $I_{e}$ represents enrichment (molar fraction) of AA or bicarbonate infusate and $\mathrm{I}$ is the rate of infusion (mmol/ min), while $E_{a}$ is the mean enrichment of the metabolite (mol fraction) in arterial plasma. Outflow from plasma 
AA pool (tracee + tracer; $\mathrm{mmol} / \mathrm{h}$ ) was calculated as:

$$
\left(\mathrm{I}_{\mathrm{e}} / \mathrm{E}_{\mathrm{a}}\right) \times \mathrm{I} \text {. }
$$

It was assumed that the equivalent of the infused dose was in excess of body needs and was oxidised, with tracee and tracer metabolised similarly. Therefore, whole-body tracee oxidation (WBO) of AA $(\mathrm{mmol} / \mathrm{h})$ was calculated as:

(whole-body outflow $\times$ fraction dose oxidised) - dose infused.

The fraction of the dose oxidised was calculated as:

$$
\left(\mathrm{E}_{\mathrm{a},}, \mathrm{CO}_{2} \times \mathrm{WBF}_{\mathrm{CO}_{2}}\right) /\left(\mathrm{E}_{\mathrm{d}} \times \mathrm{I}\right),
$$

where $\mathrm{E}_{\mathrm{a}, \mathrm{CO}_{2}}$ is the enrichment (atom \% excess) of $\mathrm{CO}_{2}$ in arterial plasma, $\mathrm{WBF}_{\mathrm{CO}_{2}}$ is whole-body flux (production; $\mathrm{mmol} / \mathrm{h}$ ) of $\mathrm{CO}_{2}$ and $\mathrm{E}_{\mathrm{d}}$ is the enrichment of the infusate.

For phenylalanine, an alternative approach could be adopted based on the production of tyrosine (as the $1{ }^{13} \mathrm{C}$ form) from hydroxylation of phenylalanine, the first stage in the degradative pathway. Total tyrosine $(\mathrm{mmol} / \mathrm{h})$ from phenylalanine is given by:

tyrosine outflow (tracee + tracer)

$\times$ fraction of tyrosine from phenylalanine,

where the fraction converted is obtained from the relative enrichments of $\left[1-{ }^{13} \mathrm{C}\right]$ tyrosine: $\left[1-{ }^{13} \mathrm{C}\right]$ phenylalanine ratio. The tracee tyrosine from phenylalanine is then obtained by subtracting the dose of phenylalanine infused (again it is assumed that this is all oxidised).

Use of AA for WBPS $(\mathrm{mmol} / \mathrm{h})$ was calculated as irreversible loss rate - WBO. This was converted into $g$ protein synthesised/d by:

$$
\text { WBPS } \times 24 \times 0 \cdot 1 \times \mathrm{MM}_{\mathrm{aa}} /(\% \text { AA in protein }),
$$

where $\mathrm{MM}_{\mathrm{aa}}$ is the molecular mass of the AA, and (\% AA in protein) is the average content $(\mathrm{g} / 100 \mathrm{~g})$ of the AA in body protein (MacRae et al. 1993).

Apparent oxidation of AA (AOAA) across the gut (mmol ${ }^{13} \mathrm{CO}_{2}$ appearance/min) was calculated as:

$$
\mathrm{PF}_{\mathrm{m}} \text { or } \mathrm{p} \times\left(\left(\mathrm{B}_{\mathrm{m}} \text { or } \mathrm{p} \times \mathrm{E}_{\mathrm{CO}_{2}, \text { m or } \mathrm{p}}\right)-\left(\mathrm{B}_{\mathrm{a}} \times \mathrm{E}_{\mathrm{CO}_{2}}, \mathrm{a}\right)\right) \text {, }
$$

where $\mathrm{B}$ is the relevant plasma bicarbonate concentration (mM). During the bicarbonate infusions, the appearance of total ${ }^{13} \mathrm{CO}_{2}$ label in the venous drainage of the MDV and PDV was less than that in the arterial inflow. This was due to sequestration (isotopic exchange) of label by the digestive tract tissues. The sequestration (sq) was determined for each sheep from:

$$
\left(\left(\mathrm{B}_{\mathrm{a}} \times \mathrm{E}_{\mathrm{CO}_{2}, \mathrm{a}}\right)-\left(\mathrm{B}_{\mathrm{m} \text { or }} \times \mathrm{E}_{\mathrm{CO}_{2}, \mathrm{~m} \text { or p }}\right)\right) /\left(\mathrm{B}_{\mathrm{a}} \times \mathrm{E}_{\mathrm{CO}_{2}, \mathrm{a}}\right) \text {. }
$$

On average, this represented $3.3 \%$ of arterial inflow of labelled plasma bicarbonate for both PDV and MDV. This is greater than reported sequestration across the PDV of dogs (2\%; Gresham et al. 2000). While this may reflect species differences, the canine study is unusual in that whole-body bicarbonate recovery exceeded $97 \%$, whereas in the ovine (Ram et al. 1999) and human subjects (see Leijssen \& Elia, 1996) lower recoveries (i.e. higher sequestration) of $<85 \%$ are reported.

Oxidation (tracer + tracee) by the MDV or PDV tissues was then calculated as:

$$
\mathrm{AOAA}+\left(\mathrm{Sq} \times \text { arterial inflow }{ }^{13} \mathrm{C} \text { bicarbonate }\right)
$$

To obtain from this the oxidation of tracee by the tissue (TO, $\mathrm{mmol} / \mathrm{h}$ ) it is assumed that the partition of oxidation between body organs is the same for tracer and tracee such that:

$$
\left(\mathrm{TO}_{\text {tracer+tracee }}\right) /\left(\mathrm{WBO}_{\text {tracer+tracee }}\right)=\left(\mathrm{TO}_{\text {tracee }}\right) /\left(\mathrm{WBO}_{\text {tracee }}\right) \text {, }
$$

so that:

$$
\mathrm{TO}=\mathrm{WBO}_{\text {tracee }} \times \mathrm{TO}_{\text {tracer+tracee }} / \mathrm{WBO}_{\text {tracer+tracee }} .
$$

Similar reasoning was applied for trace AA use for protein synthesis ( $\mathrm{mmol} / \mathrm{h})$ across the MDV and PDV:

$$
\mathrm{TPS}=\mathrm{WBPS}_{\text {tracee }} \times \mathrm{TPS}_{\text {tracer+tracee }} / \mathrm{WBPS}_{\text {tracer+tracee }},
$$

where TPS is the total protein synthesis. For these calculations, various pools (and corresponding enrichments) were selected as being most representative of the precursor for protein synthesis. This was usually taken as the artery for comparison with whole-body flux calculations or the appropriate vein (see p. 619). These values could be converted into values expressed as $\mathrm{g}$ protein/d by a similar equation as that used for whole-body flux calculations.

\section{Statistics}

All comparisons were by ANOVA using GenStat for Windows (version 6, release 6.1.0.200; Lawes Educational Trust, Rothamsted, Herts., UK). For main effects, animals and periods were treated as blocks, but if period was found not to be significant (the usual situation) then the data were re-analysed with period omitted. For net movements of individual AA, $\mathrm{NH}_{3}$ and urea, animal and day of sampling were treated as blocks and site of sample (MDV and PDV) as treatment. The PDV:MDV appearance ratio was examined for groups of AA (essential or non-essential), again blocked for animal and day of sampling. These data were restricted to three sheep only, due to problems with the placement of the mesenteric catheter tip. For isotope-related measurements, data were again analysed with sheep and period as blocks and the latter subsequently removed if found not to be significant. The enrichments of natural abundance bicarbonate in blood between the various sites were also compared. This involved the mean of triplicate analysis for three samples (number), from each blood vessel at five periods (before each infusion). These were analysed with animal, period and number as blocks and with vessel as treatment.

\section{Results}

\section{Mass transfers across the gastrointestinal tract}

Plasma flows and non-amino-acid-N transfers. In one sheep the tip of the cranial mesenteric catheter tip was 
found adhered to the vessel wall at analysis post mortem. For this sheep, MDV flows and analyses were not included in the data.

There was no effect of either sheep or AA infusion on PDV plasma flow (1.64 (SD 0.19) kg/min). In contrast, for MDV flow $(0.83(\mathrm{SD} 0 \cdot 18) \mathrm{kg} / \mathrm{min})$, there were effects between sheep $(P=0.023)$, although not between AA infusion. The animal effect was also apparent $(P=0.014)$ for the MDV:PDV plasma flow ratios (0.50 (SD 0.12)). The animal differences in MDV flow may relate to position of the catheter tip during sampling and whether caecal vein inflow was included or not. With such surgical preparations, catheter tip placement is always slightly uncertain due to the flexibility of the GIT and the physical movements associated with the free postural changes permitted during the measurements.

There was net production $(P<0.001)$ of $\mathrm{NH}_{3}$ across the GIT, with approximately $42 \%$ absorbed from the small intestine into the mesenteric vein (Table 1). In contrast, there was consistent uptake $(P<0.001)$ of urea-N by the GIT with approximately $45 \%$ of total removal across the GIT occurring across the MDV (Table 1). These results indicate that it would be erroneous to think at all $\mathrm{NH}_{3}$ appearing in the portal vein is derived from rumen fermentation. Clearly other mechanisms, such as deamination of AA in the small intestine (Windmueller \& Spaeth, 1980; Gate et al. 1999) can be quantitatively important.
The proportions of $\mathrm{NH}_{3}$ absorbed from the rumen and the lower digestive tract might vary with both the nature of feed offered and the feeding frequency. The observation that non-salivary urea entry to the GIT is also not exclusive to the rumen agrees with other reports (see Lapierre \& Lobley, 2001). While urea-N removal accounted, numerically, for approximately $70 \%$ of the $\mathrm{NH}_{3}$ appearance across both the MDV and PDV, direct determination of the fate of the urea-N would require use of isotope kinetics. It is known, however, that under similar experimental conditions at least $40 \%$ of urea-N entry to the GIT is returned to the liver in the form of $\mathrm{NH}_{3}$ (Sarraseca et al. 1998).

In terms of total $\mathrm{N}$ absorbed (i.e. $\mathrm{NH}_{3}+\mathrm{AA}-\mathrm{N}$ ), the fraction from $\mathrm{NH}_{3}$ increased $(P<0.001)$ from 0.31 across the MDV to 0.63 for the whole GIT. When allowance was made for urea-N inputs, however, the relative amounts were 0.10 and 0.35 respectively; this probably reflects the net fates of absorbed dietary-N better. An 'apparent' digestibility value of 0.47 can be determined from the PDV N-balance value $\left(\mathrm{AA}-\mathrm{N}+\mathrm{NH}_{3}-\mathrm{N}-\right.$ urea-N ; Table 1) expressed against $\mathrm{N}$ intake $(79.8 \mathrm{mmol} / \mathrm{h})$. These do not include $\mathrm{N}$ 'digested' in other forms e.g. nucleic acid-N, amino sugars, nitrate and, most notably, arginine and citrulline. These latter will probably contribute $8.3 \mathrm{mmol} \mathrm{N} / \mathrm{h}$ to PDV net absorption (from Lobley et al. 2001) and would increase the digestibility value to $0 \cdot 57$. This compares with digestibility values of 0.63 determined

Table 1. Net absorption (mmol/h) of amino acids $(A A)$, urea and ammonia across the mesenteric-drained viscera (MDV) and portal-drained viscera (PDV) of sheep offered $1200 \mathrm{~g}$ grass pellets $/ \mathrm{d}^{*}$

\begin{tabular}{|c|c|c|c|c|c|}
\hline & MDV & PDV & SED & Statistical significance of effect (ANOVA): $P \dagger$ & PDV:MDV \\
\hline \multicolumn{6}{|l|}{ Non-essential AA } \\
\hline Alanine & 4.062 & 3.198 & 0.219 & 0.002 & $0 \cdot 823^{\mathrm{bc}}$ \\
\hline Aspartate & 0.612 & 0.594 & 0.043 & NS & $1 \cdot 014^{\mathrm{a}}$ \\
\hline Glutamate & 1.572 & 1.302 & 0.069 & 0.003 & $0.839^{a b}$ \\
\hline Glutamine & -0.684 & $-1 \cdot 710$ & 0.107 & $<0.001$ & - \\
\hline Glycine & 3.642 & 2.682 & 0.157 & $<0.001$ & $0.738^{\mathrm{bc}}$ \\
\hline Proline & 1.638 & 1.074 & 0.067 & $<0.001$ & $0 \cdot 655^{\mathrm{c}}$ \\
\hline Serine & 2.442 & 1.872 & 0.089 & $<0.001$ & $0.772^{\mathrm{bc}}$ \\
\hline Tyrosine & 1.560 & $1 \cdot 158$ & 0.082 & $<0.001$ & $0.767^{\mathrm{bc}}$ \\
\hline SED & & & & & 0.0670 \\
\hline \multicolumn{6}{|l|}{ Essential AA } \\
\hline Histidine & 0.774 & 0.546 & 0.029 & $<0.001$ & $0.711^{\mathrm{b}}$ \\
\hline Isoleucine & $2 \cdot 130$ & 1.290 & 0.088 & $<0.001$ & $0.610^{\mathrm{cd}}$ \\
\hline Leucine & 3.450 & 1.902 & 0.180 & $<0.001$ & $0.559^{\text {de }}$ \\
\hline Lysine & $2 \cdot 280$ & 1.590 & 0.110 & $<0.001$ & $0.714^{\mathrm{b}}$ \\
\hline Methionine & 0.732 & 0.480 & 0.046 & $<0.001$ & $0.670^{\mathrm{bc}}$ \\
\hline Phenylalanine & 1.872 & 1.482 & 0.089 & 0.001 & $0.811^{a}$ \\
\hline Threonine & $2 \cdot 154$ & 1.344 & 0.097 & $<0.001$ & $0.629^{\text {bcd }}$ \\
\hline Tryptophan & 0.510 & 0.258 & 0.024 & $<0.001$ & $0.478^{\mathrm{e}}$ \\
\hline Valine & 2.634 & 1.572 & 0.109 & $<0.001$ & $0.589^{\text {cd }}$ \\
\hline SED & & & & & 0.0326 \\
\hline \multicolumn{6}{|l|}{ Others } \\
\hline Ammonia & 15.54 & $37 \cdot 38$ & 2.538 & $<0.001$ & \\
\hline Urea-N & -11.46 & -25.62 & $2 \cdot 016$ & $<0.001$ & \\
\hline$A A-N$ & $35 \cdot 16$ & 21.90 & 1.518 & $<0.001$ & \\
\hline $\mathrm{N}$ balance ${ }^{\S}$ & $40 \cdot 50$ & 37.52 & 3.072 & NS & \\
\hline
\end{tabular}

$\mathrm{a}, \mathrm{b}, \mathrm{c}, \mathrm{d}, \mathrm{e}$ Mean values within a column and subsection (i.e. non-essential and essential AA compared seperately) with unlike superscript letters were significantly different $(P<0.01)$.

${ }^{*}$ For details of procedures, see p. 620.

† Mean values based on four measurement days for each of four sheep, ANOVA with animal and day as blocks and site as treatment, with 11 residual df (four missing values, all MDV results for one sheep).

$\ddagger$ Values of ratios based on three sheep only, by ANOVA with animals and day of infusion treated as blocks, sample site as treatment, 66 and 88 residual df for non-essential and essential AA respectively.

$\S$ Calculated as (AA-N + ammonia) - urea-N. 
by $\mathrm{N}$ balance for the same diet in other studies (results not shown).

Net amino acid absorption. For the AA examined, net appearance across the MDV exceeded PDV appearance $(P<0.01)$, except for aspartate, where appearances were not different, and glutamine, where net disappearance occurred across both the MDV and PDV, with greater removal $(P<0 \cdot 001)$ across the latter (Table 1$)$.

The PDV : MDV appearance ratio yields the proportion of net AA absorbed across the small intestine that is then either catabolised or used to support metabolism in the other sections of the GIT i.e. the forestomachs, hindgut, pancreas and spleen. This ratio differed $(P<0.001)$ between the essential AA. A greater proportion of net uptake into the mesenteric vein appeared in the portal vein for phenylalanine $(0.81, P<0.01 v$. all other AA), while the lowest value was observed for tryptophan (0.48, $P<0.05$ for leucine, $P<0.01$ for valine, $P<0.001$ for the other essential AA). While histidine and lysine had similar PDV: MDV appearance ratios, these were higher $(P<0.01)$ than observed for threonine, isoleucine, valine and leucine. Similarly, methionine and threonine ratios were greater $(P<0 \cdot 01)$ than for leucine, although the branched-chain AA were not different from each other. There were also differences in the PDV: MDV appearance ratios for the non-essential AA with aspartate (at unity) greater $(P<0.05$ for glutamate, $P<0.01$ for the other non-essential AA) than all the others. Proline had the lowest ratio $(0.66)$ and this was lower $(P<0.05)$ than that observed for alanine (0.79) and glutamate $(0.83)$.

\section{Isotope kinetics}

Whole-body irreversible loss rate and oxidation. Wholebody $\mathrm{CO}_{2}$ entry rate was consistent between sheep (CV $1.5 \%$ ), while whole-body irreversible loss rates for the AA were more variable $(\mathrm{CV}$ from $3 \%$ for leucine to $13 \%$ for methionine) (Table 2). Both the absolute $(0.49-1.93 \mathrm{mmol} / \mathrm{h})$ and fractional rates $(0.12-0.25)$ of tracee oxidation differed markedly between AA. The fractional rates of combined tracee + tracer oxidation of leucine were greater (38\%) than normally reported (e.g. Lobley et al. 1996b; Lapierre et al. 2002), due to the larger amounts of isotope infused in order to be able to detect the differences in $\mathrm{CO}_{2}$ isotopic enrichments across the intestinal tract more precisely. Estimates of phenylalanine oxidation based on hydroxylation to tyrosine were lower than those calculated from ${ }^{13} \mathrm{CO}_{2}$ production $(0.23$ v. $0.49 \mathrm{mmol} / \mathrm{h}, P=0.013)$. The whole-body irreversible loss rate used for protein synthesis differed between AA (range $1.49-5.83 \mathrm{mmol} / \mathrm{h}$ ), but when corrected for the proportion of each AA in body mixed protein, then rates (as $g$ protein synthesis/d) were more similar (range 244-310 g/d, SED 21), but with greater estimates $(P<0.05)$ based on methionine compared with lysine.

\section{Gastrointestinal metabolism}

$\mathrm{CO}_{2}$ transfers across the gastrointestinal tract. Natural abundance enrichments (atom \%) of blood $\mathrm{CO}_{2}$ differed between sample sites (1.09058, 1.09028, 1.09052 (SED $0.00003,118$ residual df, $P<0.001)$ for arterial, mesenteric and portal vein samples respectively) (Table 3 ). Arterial and portal vein enrichments were similar, but both were greater than for mesenteric vein samples.

During $1-{ }^{13} \mathrm{C}$-labelled AA infusions, apparent appearance of ${ }^{13} \mathrm{CO}_{2}$ across the PDV, uncorrected for isotope sequestration, was positively different from zero $(P<0.01)$ only for leucine (Table 3$)$. For lysine and phenylalanine, mean values were negative, similarly for MDV measurements. Most of this could be attributed to sequestration of ${ }^{13} \mathrm{C}$ from arterial bicarbonate inflow. This was consistent across the four sheep: 0.033 (SD 0.002) of the PDV inflow and 0.033 (SD 0.005) of the MDV inflow. Correction for sequestration approximately doubled ${ }^{13} \mathrm{CO}_{2}$ appearance from leucine and all values for methionine were positive (Table 3). For lysine, corrected oxidation averaged zero, while for phenylalanine the mean values were slightly negative (but not significantly different from zero). Oxidation across the PDV was larger than across the MDV for leucine $(P<0.001)$, but only numerically so for methionine.

Table 2. Whole-body amino acid (AA) kinetics and oxidation during infusion of $\left[1-{ }^{13} \mathrm{C}\right]$ leucine, $\left[1-{ }^{13} \mathrm{C}\right] \mathrm{lysine},\left[1-{ }^{13} \mathrm{C}\right] \mathrm{methionine}$ and $\left[1-{ }^{13} \mathrm{C}\right]$ phenylalanine ${ }^{*} \dagger$

(Mean values with their standard errors for four sheep)

\begin{tabular}{|c|c|c|c|c|c|c|c|c|c|c|c|c|}
\hline \multirow[b]{2}{*}{ WB fluxes $(\mathrm{mmol} / \mathrm{h})$} & \multirow[b]{2}{*}{ Mean } & \multirow[b]{2}{*}{ SEM } & \multicolumn{2}{|c|}{ Leu } & \multicolumn{2}{|c|}{ Lys } & \multicolumn{2}{|c|}{ Met } & \multicolumn{2}{|c|}{ Phe } & \multicolumn{2}{|c|}{ (Tyr)† } \\
\hline & & & Mean & SEM & Mean & SEM & Mean & SEM & Mean & SEM & Mean & SEM \\
\hline $\begin{array}{l}\text { ILR } \ddagger \\
\mathrm{CO}_{2} \text { entry rate }\end{array}$ & 978 & $7 \cdot 1$ & $7 \cdot 76$ & 0.10 & 4.92 & 0.27 & 1.99 & 0.13 & $3 \cdot 31$ & 0.19 & $2 \cdot 92$ & 0.24 \\
\hline WBO & & & 1.93 & 0.14 & 0.61 & $0 \cdot 10$ & 0.50 & 0.04 & 0.49 & 0.04 & & \\
\hline WBO/ILR & & & 0.25 & 0.02 & 0.12 & 0.02 & 0.25 & 0.02 & 0.17 & 0.01 & & \\
\hline $\mathrm{ILR}_{\mathrm{ps}} \S$ & & & 5.83 & 0.07 & $4 \cdot 31$ & 0.19 & 1.49 & 0.11 & $2 \cdot 82$ & 0.13 & & \\
\hline WBPS $(\mathrm{g} / \mathrm{d}) \boldsymbol{q}$ & & & 270 & & 244 & & 310 & & 284 & & & \\
\hline
\end{tabular}

WB, whole-body; Leu, leucine; Lys, lysine; Met, methionine; Phe, phenylalanine; Tyr, tyrosine; ILR, irreversible loss rate; WBO, whole-body oxidation; WBPS, whole-body protein synthesis.

${ }^{*}$ For details of procedures, see p. 619

†Phenylalanine infusion also included $\left[{ }^{2} \mathrm{H}_{4}\right]$ tyrosine.

$¥$ Tracee ILR were based on mean values of arterial enrichments for each of four sheep.

$\S$ ILR - WBO (tracee only).

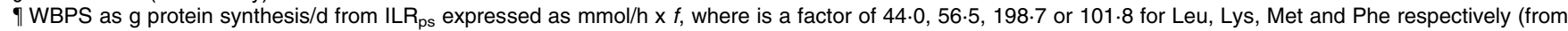
MacRae et al. 1993). 
Table 3. Production of ${ }^{13} \mathrm{CO}_{2}(\mu \mathrm{mol} / \mathrm{h})$ across the mesenteric-drained viscera (MDV) and portal-drained viscera (PDV) during infusion of $\left[1-{ }^{13} \mathrm{C}\right]$ leucine, $\left[1-{ }^{13} \mathrm{C}\right] \mathrm{lysine},\left[1-{ }^{13} \mathrm{C}\right]$ methionine and $\left[1-{ }^{13} \mathrm{C}\right]$ phenylalanine $\dagger$

(Mean values for four sheep (three only for MDV) with mean values of triplicate analysis of three samples taken hourly)

\begin{tabular}{|c|c|c|c|c|c|c|}
\hline \multirow[b]{2}{*}{${ }^{13} \mathrm{CO}_{2}$ production $(\mu \mathrm{mol} / \mathrm{h})$} & \multicolumn{4}{|c|}{$\left[1-{ }^{13} \mathrm{C}\right]$ infusate } & \multirow[b]{2}{*}{ SED } & \multirow[b]{2}{*}{ Statistical significance of effect (ANOVA): $P \ddagger$} \\
\hline & Leucine & Lysine & Methionine & Phenylalanine & & \\
\hline \multicolumn{7}{|l|}{ Uncorrected } \\
\hline MDV & $9 \cdot 7^{\mathrm{a}}$ & $-5 \cdot 4^{\mathrm{b}}$ & $0.0^{\mathrm{ab}}$ & $-5 \cdot 1^{b}$ & 5.46 & 0.098 \\
\hline PDV & $32 \cdot 2^{\mathrm{a} *}$ & $-4 \cdot 7^{\mathrm{b}}$ & $-0.4^{\mathrm{b}}$ & $-8 \cdot 4^{b}$ & 3.69 & $<0.001$ \\
\hline \multicolumn{7}{|l|}{ Corrected } \\
\hline MDV & $19 \cdot 6^{\mathrm{a}}$ & $-3 \cdot 3^{b}$ & $4 \cdot 0^{b}$ & $-1 \cdot 5^{b}$ & $6 \cdot 48$ & 0.040 \\
\hline PDV & $52 \cdot 0^{\mathrm{a} *}$ & $-0.0^{\mathrm{b}}$ & $7 \cdot 6^{\mathrm{b}}$ & $-1 \cdot 2^{b}$ & 4.55 & $<0.001$ \\
\hline \multicolumn{7}{|l|}{ Dose oxidised (\%) } \\
\hline MDV & $2 \cdot 9^{a}$ & $-1.4^{c}$ & $1 \cdot 8^{\mathrm{ab}}$ & $-0.5^{\mathrm{bc}}$ & 1.05 & 0.022 \\
\hline PDV & $7 \cdot 6^{\mathrm{a*}}$ & $-0.3^{\mathrm{b}}$ & $3 \cdot 3^{c}$ & $-0.4^{\mathrm{c}}$ & 0.89 & $<0.001$ \\
\hline WB & $30 \cdot 9^{\mathrm{a}}$ & $17 \cdot 1^{\mathrm{b}}$ & $33 \cdot 1^{a}$ & $21 \cdot 7^{\mathrm{c}}$ & 1.67 & $<0.001$ \\
\hline \multicolumn{7}{|l|}{ WB oxidation (\%) } \\
\hline MDV & $9 \cdot 5^{\mathrm{a}}$ & $-7 \cdot 6^{c}$ & $5 \cdot 0^{\mathrm{ab}}$ & $-2 \cdot 2^{\mathrm{bc}}$ & 3.92 & 0.019 \\
\hline PDV & $24 \cdot 8^{\mathrm{a} *}$ & $-0.9^{c}$ & $9 \cdot 9^{\mathrm{b}}$ & $-1.9^{C}$ & 3.58 & $<0.001$ \\
\hline
\end{tabular}

WB, whole-body.

$\mathrm{a}, \mathrm{b}, \mathrm{c}$ Mean values with a row with unlike superscript letters were significantly different $(P<0.05)$.

Mean values were significantly different from those of MDV (comparisons between MDV and PDV were for three sheep only by ANOVA with animals as blocks and amino acid $\times$ site as treatment, 14 residual $\mathrm{df}$ ): ${ }^{*} P<0.05$.

†For details of procedures, see p. 620.

$\ddagger$ Animal as block and amino acid as treatment (no period effect), 9 residual df for PDV and 6 residual df for MDV (one animal missing).

In part, the absolute appearance of ${ }^{13} \mathrm{CO}_{2}$ is a function of the dose infused: a better reflection of the response at both the whole-body and GIT level is obtained when the data are expressed relative to the amount of labelled AA supplied. The proportion of the dose oxidised by the PDV was $8.0 \%$ for leucine and $3.3 \%$ for methionine. These represented $25 \%$ and $10 \%$ of WBO. These values can be converted into tracee oxidation by the GIT and, under the dietary conditions employed in the present study, this amounted to 0.52 and $0.05 \mathrm{mmol} / \mathrm{h}$ for leucine and methionine respectively. Thus, net absorption was reduced by 25 and $11 \%$ respectively. In contrast, for neither lysine nor phenylalanine was oxidation across the PDV different from zero, even though WBO accounted for 16 and $22 \%$ of the dose respectively.

\section{Metabolite enrichments}

Enrichments of the infused $1-{ }^{13} \mathrm{C}$-labelled AA and $\left[{ }^{2} \mathrm{H}_{4}\right]$ tyrosine were all greater $(P<0.01)$ in the arterial plasma than either of the mesenteric or portal venous samples. This is due to dilution, either from unlabelled AA absorbed from the feed or released from protein degradation within the GIT tissues. Enrichments in the mesenteric vein were lower $(P<0 \cdot 01)$ than in the portal vein for all AA except lysine. In contrast, during the leucine infusion, MOP enrichments were similar between arterial and portal veins, but slightly lower $(4 \%, P=0.004)$ for the mesenteric vein. As a consequence, the MOP: leucine ratio increased from 0.85 in arterial plasma to 1.20 in the mesenteric vein $(P=0.003)$ (Table 4). During lysine infusions, the 2-aminoadipate: lysine enrichment ratio in arterial plasma (0.53) was lower $(P<0.001)$ than for the corresponding MOP : leucine ratio. Similarly to MOP, however, the enrichment of 2-aminoadipate did not alter across the GIT and, in consequence, the ratio against lysine increased to $0.74(P=0.03)$ in the mesenteric vein. Glutamate enrichments remained low in all plasma samples $(<0 \cdot 4$ molar \% excess, results not shown).

As with MOP and 2-aminoadipate, the product of methionine metabolism, homocysteine, also had a lower enrichment in arterial plasma than the parent molecule (ratio 0.74). Again, there was no change in homocysteine enrichment across the GIT, but the homocysteine : methionine ratio increased to unity and greater $(P<0.001)$ for the portal and mesenteric veins respectively. A later metabolite of the degradation pathway, 2-aminobutyrate, had enrichments $<40 \%$ those of homocysteine, while the corresponding oxo-acid, 2-oxo-butyrate, was lower still. The enrichment of neither 2-aminobutyrate nor 2-oxo-butyrate was changed during passage across the digestive tract. During methionine infusion, label incorporation into homoserine was observed, but this also was unchanged by transit across the GIT and did not exceed $0 \cdot 14$ of the corresponding $\left[1-{ }^{13} \mathrm{C}\right]$ methionine enrichment.

During infusion of $\left[1-{ }^{13} \mathrm{C}\right]$ phenylalanine, $\left[1-{ }^{13} \mathrm{C}\right]$ tyrosine was formed. Although the enrichment of the latter differed $(P<0.001)$ between the three sample sites, the ratio against the corresponding $\left[1-{ }^{13} \mathrm{C}\right]$ phenylalanine was constant $(0 \cdot 17-0 \cdot 18)$. This yielded values of 0.51 (SD 0.08$) \mathrm{mmol} /$ $\mathrm{h}$ for whole-body phenylalanine hydroxylation.

Gastrointestinal tract amino acid gross fluxes. As expected, estimates of protein synthesis across both the MDV and PDV were higher $(P<0.001)$ when corresponding venous, rather than arterial, free AA enrichments were chosen as precursor. The contribution of the MDV to total GIT (i.e. PDV) protein synthesis was $42-50 \%$ based on arterial precursor and $52-60 \%$ based on venous plasma across all AA (Table 5). When all data were compared with arterial free AA as precursor, then the contribution of the MDV to WBPS ranged from 16-28\% for the MDV and between 37-59\% for the PDV, between the 
Table 4. Isotopic enrichments (molar \% excess) of primary and secondary metabolites in arterial (A), portal vein (PV) and mesenteric vein (MV) plasma following infusion of $1-{ }^{13} \mathrm{C}$-labelled amino acids into the hepatic vein* (Mean values for four sheep)

\begin{tabular}{|c|c|c|c|c|c|}
\hline Amino acid infused & A & MV & PV & SED & Statistical significance of effect (one-way ANOVA): $P \dagger$ \\
\hline \multicolumn{6}{|l|}{ Leucine } \\
\hline$\left[1-^{13}\right.$ C]leucine & $8.04^{a}$ & $5 \cdot 65^{\mathrm{b}}$ & $6 \cdot 46^{\mathrm{c}}$ & 0.297 & 0.001 \\
\hline$\left[1-{ }^{13} \mathrm{C}\right] \mathrm{MOP}$ & $6.79^{\mathrm{a}}$ & $6 \cdot 60^{\mathrm{b}}$ & $6 \cdot 86^{a}$ & 0.042 & 0.004 \\
\hline MOP:leucine & $0.85^{a}$ & $1 \cdot 20^{\mathrm{b}}$ & $1.06^{\mathrm{C}}$ & 0.054 & 0.003 \\
\hline \multicolumn{6}{|l|}{ Lysine } \\
\hline$\left[1-{ }^{13} \mathrm{C}\right]$ lysine $\ddagger$ & $5 \cdot 41^{\mathrm{a}}$ & $4 \cdot 20^{\mathrm{b}}$ & $4.57^{\mathrm{b}}$ & 0.242 & 0.010 \\
\hline$\left[1-{ }^{13} \mathrm{C}\right] \mathrm{AAA} \ddagger$ & $2 \cdot 74$ & $2 \cdot 87$ & $2 \cdot 85$ & 0.113 & NS \\
\hline AAA:Iysine & $0.53^{a}$ & $0.74^{\mathrm{b}}$ & $0.64^{\mathrm{ab}}$ & 0.052 & 0.026 \\
\hline \multicolumn{6}{|l|}{ Methionine } \\
\hline$\left[1-{ }^{13} \mathrm{C}\right]$ Methionine & $10 \cdot 58^{\mathrm{a}}$ & $6 \cdot 45^{\mathrm{b}}$ & $7 \cdot 83^{c}$ & 0.185 & $<0.001$ \\
\hline$\left[1-{ }^{13} \mathrm{C}\right] \mathrm{HC}$ & 7.59 & $7 \cdot 60$ & $7 \cdot 68$ & 0.055 & NS \\
\hline HC:methionine & $0 \cdot 74^{a}$ & $1 \cdot 21^{b}$ & $1.01^{c}$ & 0.046 & $<0.001$ \\
\hline$\left[1-{ }^{13} \mathrm{C}\right] \mathrm{AAB}$ & $2 \cdot 82$ & $2 \cdot 61$ & $2 \cdot 71$ & 0.217 & NS \\
\hline$\left[1-{ }^{13} \mathrm{C}\right] \mathrm{OB}$ & 1.53 & 1.30 & $1 \cdot 71$ & 0.136 & NS \\
\hline$O B: A A B$ & 0.62 & 0.52 & 0.68 & 0.116 & NS \\
\hline$\left[1-{ }^{13} \mathrm{C}\right]$ Homoserine & 0.88 & 0.89 & 0.72 & 0.121 & NS \\
\hline \multicolumn{6}{|l|}{ Phenylalanine $+\left[{ }^{2} \mathrm{H}_{4}\right]$ tyrosine } \\
\hline$\left[1-{ }^{13} \mathrm{C}\right]$ Phenylalanine & $8 \cdot 18^{a}$ & $5 \cdot 14^{b}$ & $6 \cdot 28^{c}$ & 0.218 & $<0.001$ \\
\hline$\left[1-{ }^{13} \mathrm{C}\right]$ Tyrosine & $1.41^{a}$ & $0.90^{\mathrm{b}}$ & $1 \cdot 11^{\mathrm{c}}$ & 0.043 & $<0.001$ \\
\hline$\left[1-{ }^{13} \mathrm{C}\right]$ Tyrosine: $\left[1-{ }^{13} \mathrm{C}\right]$ Phenylalanine & 0.17 & 0.18 & 0.18 & 0.006 & NS \\
\hline$\left[{ }^{2} \mathrm{H}_{4}\right]$ Tyrosine & $2 \cdot 21^{a}$ & $1.63^{\mathrm{b}}$ & $1.90^{\mathrm{C}}$ & 0.040 & $<0.001$ \\
\hline
\end{tabular}

MOP, 4-methyl-2-oxopentanoate; AAA, 2-aminoadipate; HC, homocysteine; AAB, 2-aminobutyrate; OB, 2-oxobutyrate.

$\mathrm{a}, \mathrm{b}, \mathrm{c}$ Mean values within a row with unlike superscript letters were significantly different $(P<0.05)$.

${ }^{*}$ For details of procedures, see p. 620.

†Based on mean values of three plasma samples taken from each sheep during infusion of respective labelled amino acids, animals as blocks (no period effect) and site of sampling as treatment, 5 residual df (one missing value).

$\ddagger$ Alternatively, where appropriate lysine or AAA labelled with $\left[1-{ }^{13} \mathrm{C},{ }^{2} \mathrm{H}_{2}\right]$.

various AA. Absolute rates of synthesis, based on venous enrichments as precursor, also varied between the AA and ranged from $62-104 \mathrm{~g} / \mathrm{d}$ for the MDV and 97-143 for the PDV. Corresponding values based on arterial enrichments were lower by $15-44 \%$.

\section{Discussion}

There were two main questions asked in the present study. First, does the ovine GIT oxidise essential AA other than leucine? Second, do differences in oxidation (or any other mechanism) between the MDV and non-MDV tissues lead to differences in the pattern of AA presented to the liver and beyond?

Which amino acid does the gastrointestinal tract oxidise?

There is little doubt that the mammalian GIT can catabolise leucine (e.g. Pell et al. 1986; Lobley et al. 1995; Yu et al. 2000; van der Schoor et al. 2001) and, in ruminant animals,

Table 5. Protein synthesis across the mesenteric-drained viscera (MDV) and portal-drained viscera (PDV) based on use of either plasma arterial or venous enrichments of leucine, lysine and methionine for sheep offered $1000 \mathrm{~g}$ grass pellets*

(Mean values with their standard errors for four sheep)

\begin{tabular}{|c|c|c|c|c|c|c|c|c|}
\hline & \multicolumn{2}{|c|}{ Leucine } & \multicolumn{2}{|c|}{ Lysine } & \multicolumn{2}{|c|}{ Methionine } & \multicolumn{2}{|c|}{ Phenylalanine } \\
\hline & Mean & SEM & Mean & SEM & Mean & SEM & Mean & SEM \\
\hline \multicolumn{9}{|c|}{ Protein synthesis (mmol/h) } \\
\hline \multicolumn{9}{|c|}{ MDV† } \\
\hline Arterial precursor & 1.23 & 0.22 & 0.88 & 0.23 & 0.36 & 0.14 & 0.43 & 0.15 \\
\hline Venous precursor & 1.83 & 0.24 & $1 \cdot 21$ & 0.32 & 0.64 & 0.26 & 0.69 & 0.21 \\
\hline \multicolumn{9}{|l|}{ PDV } \\
\hline Arterial precursor & $2 \cdot 77$ & 0.11 & 1.60 & 0.27 & 0.63 & 0.08 & 0.91 & 0.11 \\
\hline Venous precursor & 3.45 & 0.17 & 1.89 & 0.32 & 0.85 & 0.11 & $1 \cdot 19$ & 0.11 \\
\hline \multicolumn{9}{|l|}{ MDV:PDV† } \\
\hline Arterial precursor & 0.48 & 0.08 & 0.47 & 0.09 & 0.50 & 0.09 & 0.42 & 0.07 \\
\hline Venous precursor & 0.53 & 0.08 & 0.52 & 0.12 & 0.60 & 0.14 & 0.53 & 0.08 \\
\hline \multicolumn{9}{|l|}{ Fraction of WBPS } \\
\hline MDV† & 0.28 & 0.03 & 0.19 & 0.05 & 0.27 & 0.07 & $0 \cdot 16$ & 0.04 \\
\hline PDV & 0.59 & 0.04 & 0.39 & 0.05 & 0.52 & 0.08 & 0.37 & 0.05 \\
\hline
\end{tabular}

WBPS, whole-body protein synthesis, based on arterial enrichments.

${ }^{\star}$ For details of procedures, see p. 620

†Values based on three sheep only. 
this oxidation can exceed that across the liver (Lobley et al. 1996b; Lapierre et al. 2002). Leucine oxidation appears to vary with absolute intake (Pell et al. 1986; Yu et al. 2000) as well as both protein (van der Schoor et al. 2001) and leucine supply (Lapierre et al. 2002). Furthermore, challenges that either increase (Yu et al. 2000) or reduce (MacRae et al. 1999) the metabolic demand on the GIT also alter the catabolism of leucine. This sensitivity means that the proportion of whole-body leucine oxidation attributable to GIT metabolism can vary between 0 and $50 \%$ (Lobley et al. 1995, 1996b; van der Schoor et al. 2001; Lapierre et al. 2002). The current results show a mid-range ( $26 \%$ of total oxidation), but this may be influenced by the dose of leucine infused $(8 \%$ of wholebody leucine flux; $20 \%$ of apparent absorption across the MDV). The net result was that the oxidation by the GIT lowered net absorption of leucine by $25 \%$.

The contribution of the MDV (small intestine) to PDV (whole GIT) leucine oxidation was approximately $40 \%$, similar to the only other report in lambs ( $\mathrm{Yu}$ et al. 2000). In that study, although both the MDV and non-MDV tissues (forestomach, large intestine, spleen and pancreas) were responsive to intake, the largest changes in leucine oxidation, induced by the presence of parasites in the upper small intestine, were across the MDV. By analogy, the sensitivity of leucine oxidation to protein intake in pigs (van der Schoor et al. 2001) probably occurs across the small intestine.

Although leucine has proved the most popular AA as a tracer for metabolic studies (due to lower cost and a simple two-step metabolic pathway to liberate the carboxyl-C as $\mathrm{CO}_{2}$ ), it may not be a suitable marker for other AA. This is because the enzymes responsible for transamination and decarboxylation of the branched-chain AA are widely distributed across tissues, such as liver, muscle, fat, the mammary gland as well as the GIT (Goodwin et al. 1987; Papet et al. 1988; Bequette et al. 1996). In contrast, the catabolism of other essential AA is either restricted to the liver or a limited number of other tissues (Le Floc'h et al. 1997; Mabjeesh et al. 2000). Oxidative losses of these AA across the GIT, therefore, cannot be assumed just because leucine is catabolised. The reason why leucine oxidation is widespread between tissues is unclear, but may involve a role as a signal of nutrient supply (Lobley, 1998). Indeed, leucine has recently been shown to interact directly with the signal cascades that regulate protein metabolism (Kimball \& Jefferson, 2002). In addition, the branched-chain AA act as $\mathrm{N}$ donors in transamination reactions (de Lange et al. 1992) and the resultant oxo-acids are sensitive to oxidation unless rapidly re-aminated (Cheng et al. 1985).

Of the other AA examined, labelled $\mathrm{CO}_{2}$ release across the GIT was observed only for methionine, but this only represented $10 \%$ of WBO, with a similar loss in terms of net absorption. As with leucine, methionine oxidation occurred across both the MDV and non-MDV. Again the question can be asked: 'what role would methionine catabolism play in the GIT?'. Methionine acts as an intermediate in methyl group transfers with the product, homocysteine, either being re-methylated to methionine (thus conserving the carboxyl-C) or converted to cysteine.
The latter involves the trans-sulfuration pathway, with formation from the methionine-C of 2-aminobutyrate, which is then oxidised. In sheep, tissues with an active methionine-homocysteine cycle include not only the liver and kidney, but also the duodenal mucosa (Lobley et al. 1996a). The presence of this cycle is important for tissues based on proliferative cells with a high demand for synthesis of new membrane lipids and regulation of gene expression (Wajed et al. 2001). This would certainly include the GIT, where extensive cellular divisions occur (Attaix \& Meslin, 1991). Indirect evidence suggests that cysteine may be synthesised within the human GIT (Stegink \& den Besten, 1972) and, if so, methionine-C would be catabolised.

Intestinal catabolism of enteral-supplied $\left[{ }^{13} \mathrm{C}\right]$ lysine accounted for $31 \%$ of $\mathrm{WBO}$ in pigs fed high-protein diets (van Goudoever et al. 2000), but this declined to zero when a low-protein diet was offered. Interestingly, in both pigs (van Goudoever et al. 2000) and sheep (current study) no lysine oxidation occurred when the tracer was supplied parenterally. Thus, any GIT lysine metabolism may be restricted to cells that interface with the lumen or may arise from microbial action. In this regard, recent results indicate that isolated porcine enterocytes can oxidise lysine in vitro (Ball, 2002). Such sitespecific catabolism within the GIT may be unique to lysine, however, because leucine can be oxidised from enteral and systemic sources in both sheep and pigs (MacRae et al. 1997a; van der Schoor et al. 2001), while in contrast, threonine is not degraded by the porcine GIT, regardless of whether supply is enteral or parenteral (Burrin et al. 2001).

Although the two methods to estimate whole-body phenylalanine oxidation gave different absolute values, as has also been observed in studies with well-fed human subjects (Sanchez et al. 1996), neither approach, i.e. ${ }^{13} \mathrm{CO}_{2}$ release nor change in the enrichment ratios for $\left[1-{ }^{13} \mathrm{C}\right]$ tyrosine : $\left[1-{ }^{13} \mathrm{C}\right]$ phenylalanine across the MDV or PDV, gave any indication of catabolism by the GIT. This contrasts with a recent study in pigs (Bush et al. 2003) where $34-43 \%$ of phenylalanine was catabolised when the tracer was supplied enterally, although the authors were unable to distinguish between oxidation on 'first pass' and losses of the AA (or synthesised tyrosine) re-circulated to the GIT via the blood.

The results from sheep (current study) and pigs (van Goudoever et al. 2000; Burrin et al. 2001; van der Schoor et al. 2001; Bush et al. 2003) illustrate two major points. First, although the GIT catabolises some essential AA, this may not be a universal phenomenon and, even when it occurs, the magnitude may vary between AA. Therefore, care must be exercised before making general conclusions from studies based on the fate of a single AA. Second, catabolism may differ if the AA are supplied from the lumen rather than the systemic circulation. This is despite the fact that $80 \%$ of the AA flux through GIT tissues is from plasma origin (MacRae et al. 1997a). In this context, the issues of how much AA are presented for absorption as free AA, as opposed to di- and tri-peptide forms, and the impact of metabolism by GIT bacteria need to be considered. 


\section{Pattern of absorbed amino acids}

Differential oxidation should lead to the pattern of absorbed AA being different from that disappearing from the small intestine. Indeed, early studies with sheep did report such a phenomenon (Tagari \& Bergman, 1978) and findings in sheep (Wolff \& Bergman, 1972), rodents (Windmueller \& Spaeth, 1980) and pigs (Reeds et al. 2000; Reeds \& Burrin, 2001) have shown that the GIT has specific, and substantial, demands for certain nonessential AA, including glutamate and glutamine. Reports for net losses of essential AA present a more confused picture, however. For example, in pigs the proportion of dietary methionine supply that appears in the portal vein varies with age $(48-95 \%)$, while threonine recovery remains low (38-52\%; Rerat et al. 1992; Stoll et al. 1998). Similarly, in sheep and cattle the recovery across the PDV of individual essential AA that disappeared from the small intestine varied between 43 and $95 \%$ (from MacRae et al. 1997b; Berthiaume et al. 2001).

These comparisons of ruminant animals are confounded, however, by possible over-estimation of small intestine disappearance due to flow of endogenous protein at the duodenum (Siddons et al. 1985; Ouellet et al. 2002). Such inflows may arise from either post-splanchnic (saliva) sources or from the non-MDV portion of the PDV (rumen, abomasal secretions). The latter will distort the ratio of PDV appearance: small intestine disappearance (MacRae et al. 1997b; Berthiaume et al. 2001). Further complications arise from endogenous proteins secreted directly into the small intestine. These may arise from the pancreas, bile or the cells that line the lumen. Reabsorption of any of these sources occurs from the small intestine (into the MDV drainage), but those proteins of pancreatic origin will have derived their AA from the non-MDV vasculature of the PDV. Thus, a 'double accounting' occurs, with removal from the PDV (and lowered portal vein concentrations) and increased absorption across the MDV (and higher mesenteric vein concentrations). Bile secretions (from post-PDV sources) will augment both MDV and PDV appearance, but will alter the PDV:MDV ratio because the absolute increase adds to different net flows. Similarly, secretions from the epithelial cells of the small intestine (e.g. mucins, sucrase) will also perturb the MDV:PDV appearance ratios if not completely re-absorbed. These differences between site of synthesis and re-absorption of endogenous secretions have two consequences. First, the ratio of MDV : small intestine disappearance for essential AA can exceed unity, as observed in both sheep and cattle $(0 \cdot 74-1 \cdot 32$, MacRae et al. 1997b; Berthiaume et al. 2001), depending on the magnitude of secretions from inputs such as pancreas and bile. Indeed, theoretically this ratio should be larger than observed practically (Ouellet et al. 2002; G Zuur, F Yu, RL Coop, LA Bruce, GE Lobley and JC MacRae, unpublished results), indicating that other mechanisms leading to AA loss are also occurring. Second, the ratio of essential AA appearance between PDV: MDV should always be less than unity, regardless of whether AA oxidation occurs. This is indeed the case in both sheep (0.55-0.77; from Seal \& Parker, 1996;
MacRae et al. 1997b) and cattle (0.38-0.76; Berthiaume et al. 2001). In long-term infusions with $\left[1-{ }^{13} \mathrm{C}\right]$ leucine, the impact of pre-jejunum secretions was predicted to decrease the PDV: MDV ratio for leucine by a minimum of $18-24 \%$ (G Zuur, F Yu, RL Coop, LA Bruce, GE Lobley and JC MacRae, unpublished results). This would account for approximately half of the decrease observed in both sheep and cattle $(0 \cdot 61-0.69$, Seal \& Parker, 1996; MacRae et al. 1997b; Berthiaume et al. 2001). Much of the remainder would be accounted by non-MDV oxidation of leucine (Yu et al. 2000; current study).

The impact of endogenous secretions on both absolute and relative supply will vary between AA. For example, threonine has often been reported to have either low (Rerat et al. 1992; Stoll et al. 1998) or variable (see Lapierre \& Lobley, 2001) recoveries during absorption. Usually, this is attributed to poor re-absorption of mucins, produced from goblet cells and rich in threonine, valine and proline (Mukkur et al. 1985; Lien et al. 1997). In the absence of threonine oxidation (sheep assumed to be the same as pigs; Burrin et al. 2001), then such secretions probably account for most of the $37 \%$ difference between the MDV and the PDV appearances. Although much attention has focused on threonine losses, especially in non-ruminant animals (Burrin et al. 2001), the current data indicate that tryptophan showed the lowest PDV:MDV ratio. Few data are available for this AA because of analytical difficulties, but the results suggest that there are substantial requirements for tryptophan by the non-MDV sections of the PDV. Whether this relates to endogenous secretions or metabolic needs of tissues such as the rumen remains to be elucidated. It is also possible that the GIT as a whole may operate to regulate (or at least influence) total supply to the liver and beyond. Thus, if AA were subjected to low rates of catabolism across the small intestine, this may be 'compensated' by greater metabolic use in other parts of the GIT. In the absence of measurements of AA flow at the duodenum and small intestine disappearance it is not possible to take this argument further.

Overall, there is little doubt that, in combination, AA oxidation and the pattern of endogenous secretion and reabsorption across the GIT can alter both the absolute and relative amounts supplied to the liver and peripheral tissues. Whether these are sufficient to constrain productive performance remains unclear but the demands for threonine may leave little or none available to support growth (van Goudoever et al. 2000), while enhanced catabolism of AA under challenge situations may also slow protein gain (Yu et al. 2000).

\section{Gastrointestinal protein synthesis and metabolite formation}

The use of arterio-venous approaches to measure protein synthesis is complicated by the heterogeneity of the GIT tissues and selection of a plasma metabolite that best represents the enrichment of the intracellular precursor. Ideally, what is required is a metabolite produced within the cells from the precursor AA and then exported to the 
plasma. A popular candidate for this role is plasma MOP, the oxo-acid of leucine, and this is commonly used as a surrogate intracellular precursor during $\left[1-{ }^{13} \mathrm{C}\right]$ leucine infusions to allow quantification of WBPS (Matthews et al. 1982). For this, it is assumed that outflows from the various tissues to the plasma MOP are in the same proportion as their relative rates of protein synthesis. From direct measurements, plasma MOP has been claimed to reflect enrichments of free leucine in a diverse range of tissues, including muscle (Watt et al. 1992; but see Chinkes et al. 1996), pancreas (Bennet et al. 1993) and liver (Barazzoni et al. 1999). Nonetheless, very little exchange of MOP between plasma and the splanchnic tissues occurs in either human subjects (Biolo \& Tessari, 1997) or ruminant animals (Lobley et al. 1995; Lapierre et al. 1999???). This was confirmed in the current study where MOP enrichments were lowered by only $3 \%$ in the mesenteric vein while leucine enrichments decreased by $30 \%$.

The situation is similar for homocysteine and 2-aminoadipate, intracellular products of methionine and lysine metabolism respectively. Plasma enrichments were unchanged across MDV and PDV despite a 22-39\% decrease in the respective AA enrichments. This may reflect either limited metabolite production within the GIT tissues and/or low rates of exchange with the plasma. So, although the arterial plasma enrichments of MOP, homocysteine and 2-aminoadipate were 0.85, 0.74 and 0.53 of leucine, methionine and lysine respectively, these probably reflect metabolism in tissues other than the GIT. As such, it is probably not appropriate to use these as precursors. Unfortunately, the other common option, based on AA enrichments in either the artery or vein, yielded a wide range of estimates for protein synthesis (e.g. MDV 47-76 g/d, PDV 88-133 g/d, based on arterial enrichments), although they are similar to values obtained by the large dose procedure for the total ovine GIT (70-101 g/d; Lobley et al. 1994).

Although the small intestine tissues probably comprised only $30 \%$ of total GIT mass (Burrin et al. 1990), they have higher fractional synthesis rates (Lobley et al. 1994) and hence contributed $0.42-0.50$ of protein synthesis in the complete digestive tract. These ratios are compatible with other values based on either direct isotope incorporation studies (0.41-0.50; Lobley et al. 1994), but lower than other arterio-venous measurements based on leucine kinetics ( $\mathrm{Yu}$ et al. 2000). The contribution of the total GIT to WBPS was within the range of 0.45-0.65 reported based on a multi-tracer technique (MacRae et al. 1997a). This contribution was similar regardless of whether the arterial enrichment of the $\mathrm{AA}$ or the corresponding metabolite was adopted as precursor. Thus, the contribution of the GIT to protein dynamics is even greater than for energy metabolism (19-28\%; Burrin et al. 1989). Whether there is a penalty associated with this high protein turnover remains a matter of debate (MacRae et al. 1997a), but results in both the pig and now the sheep suggest that not all essential AA have an obligate oxidation across the GIT. Therefore, any losses that do occur are more probably associated with specific consequences of incomplete re-absorption of endogenous secretions and cellular desquamation, rather than being a general feature of high rates of protein turnover within intestinal tissues.

\section{Acknowledgements}

The statistical advice from Drs G. Horgan and G. Zuur of Biomathematics and Statistics Scotland was greatly appreciated. G. L. and X. S. were funded for their stay at the Rowett Research Institute by the Science Council of China. The majority of work was funded as part of the core budget to the Rowett Research Institute from SEERAD.

\section{References}

Attaix D \& Meslin JC (1991) Changes in small intestinal mucosa morphology and cell renewal in suckling, prolonged-suckling, and weaned lambs. American Journal of Physiology 261, R811-R818.

Ball RO (2002) Definition of the amino acid requirements in pigs: partitioning between gut and muscle. In Amino Acids: Meat, Milk and More!, pp. 17-25 [H Lapierre and DR Ouellet, editors]. Quebec, Canda: Publié par la Comité organisateur du Congrés CSAS 2002.

Barazzoni R, Meek SE, Ekberg K, Wahren J \& Nair KS (1999) Arterial KIC as marker of liver and muscle intracellular leucine pools in healthy and type 1 diabetic humans. American Journal of Physiology 277, E238-E244.

Bennet WM, O'Keefe SJ \& Haymond MW (1993) Comparison of precursor pools with leucine, alpha-ketoisocaproate, and phenylalanine tracers used to measure splanchnic protein synthesis in man. Metabolism 42, 691-695.

Bequette BJ, Backwell FR, Macrae JC, Lobley GE, Crompton LA, Metcalf JA \& Sutton JD (1996) Effect of intravenous amino acid infusion on leucine oxidation across the mammary gland of the lactating goat. Journal of Dairy Science $\mathbf{7 9}$, 2217-2224.

Berthiaume R, Dubreuil P, Stevenson M, Mcbride BW \& Lapierre $H$ (2001) Intestinal disappearance and mesenteric and portal appearance of amino acids in dairy cows fed ruminally protected methionine. Journal of Dairy Science 84, 194-203.

Biolo G \& Tessari P (1997) Splanchnic versus whole-body production of alpha-ketoisocaproate from leucine in the fed state. Metabolism 46, 164-167.

Burrin DG, Ferrell CL, Britton RA \& Bauer M (1990) Level of nutrition and visceral organ size and metabolic activity in sheep. British Journal of Nutrition 64, 439-448.

Burrin DG, Ferrell CL, Eisemann JH, Britton RA \& Nienaber JA (1989) Effect of level of nutrition on splanchnic blood flow and oxygen consumption in sheep. British Journal of Nutrition $\mathbf{6 2}$, 23-34.

Burrin DG, Stoll B, van Goudoever JB \& Reeds PJ (2001) Nutrient requirements for intestinal metabolism and growth in the neonatal pig. In Digestive Physiology of Pigs, pp. 75-88 [JE Lindberg and B Ogle, editors]. New York: CAB International.

Bush JA, Burrin DG, Suryawan A, O'Connor PM, Nguyen HV, Reeds PJ, Steele NC, van Goudoever JB \& Davis TA (2003) Somatotropin-induced protein anabolism in hindquarters and portal-drained viscera of growing pigs. American Journal of Physiology 284, E302-E312.

Calder AG, Garden KE, Anderson SE \& Lobley GE (1999) Quantitation of blood and plasma amino acids using isotope dilution electron impact gas chromatography/mass 
spectrometry with U-(13)C amino acids as internal standards. Rapid Communications in Mass Spectrometry 13, 2080-2083.

Calder AG \& Smith A (1988) Stable isotope ratio analysis of leucine and ketoisocaproic acid in blood plasma by gas chromatography/ mass spectrometry. Use of tertiary butyldimethylsilyl derivatives. Rapid Communications in Mass Spectrometry 2, 14-16.

Campbell IM (1974) Incorporation and dilution values - their calculation in mass spectrally stable isotope labeling experiments. Bioorganic Chemistry 3, 386-397.

Cheng KN, Dworzak F, Ford GC, Rennie MJ \& Halliday D (1985) Direct determination of leucine metabolism and protein breakdown in humans using L-[1-13C, $15 \mathrm{~N}]$-leucine and the forearm model. European Journal of Clinical Investigation 15, 349-354.

Chinkes D, Klein S, Zhang XJ \& Wolfe RR (1996) Infusion of labeled KIC is more accurate than labeled leucine to determine human muscle protein synthesis. American Journal of Physiology 33, E67-E71.

de Lange CF, Sauer WC, Souffrant WB \& Lien KA (1992) $15 \mathrm{~N}$-leucine and $15 \mathrm{~N}$-isoleucine isotope dilution techniques versus the $15 \mathrm{~N}$-isotope dilution technique for determining the recovery of endogenous protein and amino acids in digesta collected from the distal ileum in pigs. Journal of Animal Science 70, 1848-1856.

Gate JJ, Parker DS \& Lobley GE (1999) The metabolic fate of the amido-N group of glutamine in the tissues of the gastrointestinal tract in 24 h-fasted sheep. British Journal of Nutrition 81, 297-306.

Goodwin GW, Gibboney W, Paxton R, Harris RA \& Lemons JA (1987) Activities of branched-chain amino acid aminotransferase and branched-chain 2-oxo acid dehydrogenase complex in tissues of maternal and fetal sheep. Biochemical Journal 242, $305-308$.

Gresham JD, Okamura K, Williams PE, Jabbour K \& Flakoll PJ (2000) Gastrointestinal tract, hepatic, hindlimb, and renal recovery of $\mathrm{CO}_{2}$ in vivo. Journal of Applied Physiology 89, 2000-2006.

Kimball SR \& Jefferson LS (2002) Control of protein synthesis by amino acid availability. Current Opinion in Clinical Nutrition and Metabolic Care 5, 63-67.

Lapierre H, Bernier JF, Dubreuil P, Reynolds CK, Farmer C, Ouellet DR \& Lobley GE (1999) The effect of intake on protein metabolism across splanchnic tissues in growing beef steers. British Journal of Nutrition 81, 457-466.

Lapierre H, Blouin JP, Bernier JF, Reynolds CK, Dubreuil P \& Lobley GE (2002) Effect of supply of metabolizable protein on whole body and splanchnic leucine metabolism in lactating dairy cows. Journal of Dairy Science 85, 2631-2641.

Lapierre H \& Lobley GE (2001) Nitrogen recycling in the ruminant: a review. Journal of Dairy Science 84 (suppl.), E223-E236.

Le Floc'h N, Thibault JN \& Seve B (1997) Tissue localization of threonine oxidation in pigs. British Journal of Nutrition 77, $593-603$.

Leijssen DPC \& Elia M (1996) Recovery of (CO2)-C-13 and (CO2)-C-14 in human bicarbonate studies: A critical review with original data. Clinical Science 91, 665-677.

Lien KA, Sauer WC \& Fenton M (1997) Mucin output in ileal digesta of pigs fed a protein-free diet. Zeitschrift fur Ernahrungswissenschaft 36, 182-190.

Lobley GE (1998) Nutritional and hormonal control of muscle and peripheral tissue metabolism in farm species. Livestock Production Science 56, 91-114.

Lobley GE, Bremner DM \& Brown DS (2001) Response in hepatic removal of amino acids by the sheep to short-term infusions of varied amounts of an amino acid mixture into the mesenteric vein. British Journal of Nutrition 85, 689-698.
Lobley GE, Connell A, Lomax MA, Brown DS, Milne E, Calder AG \& Farningham DA (1995) Hepatic detoxification of ammonia in the ovine liver: possible consequences for amino acid catabolism. British Journal of Nutrition 73, 667-685.

Lobley GE, Connell A, Milne E, Newman AM \& Ewing TA (1994) Protein synthesis in splanchnic tissues of sheep offered two levels of intake. British Journal of Nutrition 71, 3-12.

Lobley GE, Connell A \& Revell D (1996a) The importance of transmethylation reactions to methionine metabolism in sheep: effects of supplementation with creatine and choline. British Journal of Nutrition 75, 47-56.

Lobley GE, Weijs PJ, Connell A, Calder AG, Brown DS \& Milne E (1996b) The fate of absorbed and exogenous ammonia as influenced by forage or forage-concentrate diets in growing sheep. British Journal of Nutrition 76, 231-248.

Mabjeesh SJ, Kyle CE, Macrae JC \& Bequette BJ (2000) Lysine metabolism by the mammary gland of lactating goats at two stages of lactation. Journal of Dairy Science 83, 996-1003.

MacRae JC, Bruce LA, Brown DS \& Calder AG (1997a) Amino acid use by the gastrointestinal tract of sheep given lucerne forage. American Journal of Physiology 273, G1200-G1207.

MacRae JC, Bruce LA, Brown DS, Farningham DA \& Franklin M (1997b) Absorption of amino acids from the intestine and their net flux across the mesenteric- and portal-drained viscera of lambs. Journal of Animal Science 75, 3307-3314.

MacRae JC, Bruce LA \& Yu F (1999) The effect of flavomycin on gastrointestinal leucine metabolism and liveweight gain in lambs. South African Journal of Animal Science 29 (ISRP), 243-244.

MacRae JC, Walker A, Brown D \& Lobley GE (1993) Accretion of total protein and individual amino-acids by organs and tissues of growing lambs and the ability of nitrogen-balance techniques to quantitate protein retention. Animal Production 57, 237-245.

Matthews DE, Schwarz HP, Yang RD, Motil KJ, Young VR \& Bier DM (1982) Relationship of plasma leucine and alphaketoisocaproate during a L-[1-13C]leucine infusion in man: a method for measuring human intracellular leucine tracer enrichment. Metabolism 31, 1105-1112.

Mukkur TK, Watson DL, Saini KS \& Lascelles AK (1985) Purification and characterization of goblet-cell mucin of high $\mathrm{M}_{\mathrm{r}}$ from the small intestine of sheep. Biochemical Journal 229, 419-428.

National Research Council (2001) Protein and amino acids. In Nutrient Requirements of Dairy Cattle, pp. 43-104 Washington, DC: National Academy of Sciences.

Ouellet DR, Demers M, Zuur G, Lobley GE, Seoane JR, Nolan JV \& Lapierre H (2002) Effect of dietary fiber on endogenous nitrogen flows in lactating dairy cows. Journal of Dairy Science 85, 3013-3025.

Pape I, Lezebot N, Barre F, Arnal M \& Harper AE (1988) Influence of dietary leucine content on the activities of branched-chain amino acid aminotransferase (EC 2.6.1.42) and branched-chain alpha-keto acid dehydrogenase (EC 1.2.4.4) complex in tissues of preruminant lambs. British Journal of Nutrition 59, 475-483.

Pell JM, Caldarone EM \& Bergman EN (1986) Leucine and alpha-ketoisocaproate metabolism and interconversions in fed and fasted sheep. Metabolism 35, 1005-1016.

Ram L, Nieto R \& Lobley GE (1999) Tissue sequestration of C-labelled bicarbonate $\left[\mathrm{HCO}^{-}\right]$in fed and fasted young sheep. Comparative Biochemistry and Physiology A 122, 323-330.

Reeds PJ \& Burrin DG (2001) Glutamine and the bowel. Journal of Nutrition 131, 2505S-2508S.

Reeds PJ, Burrin DG, Stoll B \& Jahoor F (2000) Intestinal glutamate metabolism. Journal of Nutrition 130, 978S-982S. 
Rerat A, Simoes-Nunes C, Mendy F, Vaissade P \& Vaugelade P (1992) Splanchnic fluxes of amino acids after duodenal infusion of carbohydrate solutions containing free amino acids or oligopeptides in the non-anaesthetized pig. British Journal of Nutrition 68, 111-138.

Sanchez M, El Khoury AE, Castillo L, Chapman TE, Filho AB, Beaumier L \& Young VR (1996) Twenty-four-hour intravenous and oral tracer studies with L-[1-13C]phenylalanine and L- $[3,3-2 \mathrm{H} 2]$ tyrosine at a tyrosine-free, generous phenylalanine intake in adults. American Journal of Clinical Nutrition 63, 532-545.

Sarraseca A, Milne E, Metcalf MJ \& Lobley GE (1998) Urea recycling in sheep: effects of intake. British Journal of Nutrition 79, 79-88.

Seal CJ \& Parker DS (1996) Effect of intraruminal propionic acid infusion on metabolism of mesenteric- and portal-drained viscera in growing steers fed a forage diet: II. Ammonia, urea, amino acids, and peptides. Journal of Animal Science 74, 245-256.

Siddons RC, Nolan JV, Beever DE \& MacRae JC (1985) Nitrogen digestion and metabolism in sheep consuming diets containing contrasting forms and levels of N. British Journal of Nutrition 54, 175-187.

Stegink LD \& den Besten L (1972) Synthesis of cysteine from methionine in normal adult subjects: effect of alimentation. Science 178, 514-516.

Stoll B, Henry J, Reeds PJ, Yu H, Jahoor F \& Burrin DG (1998) Catabolism dominates the first-pass intestinal metabolism of dietary essential amino acids in milk protein-fed piglets. Journal of Nutrition 128, 606-614.
Tagari H \& Bergman EN (1978) Intestinal disappearance and portal blood appearance of amino acids in sheep. Journal of Nutrition 108, 790-803.

van der Schoor SRD, van Goudoever JB, Stoll B, Henry JF, Rosenberger JR, Burrin DG \& Reeds PJ (2001) The pattern of intestinal substrate oxidation is altered by protein restriction in pigs. Gastroenterology 121, 1167-1175.

van Goudoever JB, Stoll B, Henry JF, Burrin DG \& Reeds PJ (2000) Adaptive regulation of intestinal lysine metabolism. Proceedings of the National Academy of Sciences USA 97, 11620-11625.

Wajed SA, Laird PW \& DeMeester TR (2001) DNA methylation: an alternative pathway to cancer. Annals of Surgery 234, 10-20.

Watt PW, Corbett ME \& Rennie MJ (1992) Stimulation of protein synthesis in pig skeletal muscle by infusion of amino acids during constant insulin availability. American Journal of Physiology 263, E453-E460.

Windmueller HG \& Spaeth AE (1980) Respiratory fuels and nitrogen metabolism in vivo in small intestine of fed rats. Quantitative importance of glutamine, glutamate, and aspartate. Journal of Biological Chemistry 255, 107-112.

Wolff JE \& Bergman EN (1972) Metabolism and interconversions of five plasma amino acids by tissues of the sheep. American Journal of Physiology 223, 447-454.

Yu F, Bruce LA, Calder AG, Milne E, Coop RL, Jackson F, Horgan GW \& MacRae JC (2000) Subclinical infection with the nematode Trichostrongylus colubriformis increases gastrointestinal tract leucine metabolism and reduces availability of leucine for other tissues. Journal of Animal Science $\mathbf{7 8}$ 380-390. 